\title{
Renal Sodium-Potassium-Activated Adenosine Triphosphatase and Sodium Reabsorption
}

\author{
M. Martinez-Maldonado, J. C. Allen, C. Inagaki, N. Tsaparas, and \\ A. SCHWARTZ
}

From the Renal Section, Department of Medicine, and the Division of

Myocardial Biology, Brown-Fondren Cardiovascular Research and Training

Center, The Methodist Hospital, Baylor College of Medicine, and Veterans

Administration Hospital, Houston, Texas 77031

A в S T R A C T The role of renal $\mathrm{Na}^{+}, \mathrm{K}^{+}$-ATPase in sodium reabsorption was further examined in dogs in which digoxin, a specific inhibitor of the enzyme system, was infused into one renal artery in doses ranging from 0.4 to $0.9 \mu \mathrm{g} / \mathrm{kg} / \mathrm{min}$ (low dose) and from 1.0 to $4.0 \mu \mathrm{g} / \mathrm{kg} /$ min (high dose). A significant natriuresis occurred with both dose ranges which was accompanied by inhibition of $\mathrm{Na}^{+}, \mathrm{K}^{+}$-ATPase of cortex and medulla in the infused kidney. Despite over $90 \%$ enzyme inhibition in many experiments, at least $80 \%$ of the filtered sodium continued to be reabsorbed. The per cent change in enzyme activity correlated with the rate of digoxin administration and the total dose administered but not with changes in sodium excretion. Changes in medullary $\mathrm{Na}^{+}, \mathrm{K}^{+}$-ATPase activity, however, bore a direct relationship to alterations in fractional solute free water reabsorption $\left(\mathrm{T}^{\mathrm{c}}{ }_{\mathrm{H}_{2} \mathrm{O}}\right)$. Inhibition of cortical enzyme activity alone was not associated with natriuresis, suggesting that medullary enzyme activity must be depressed for increased sodium excretion to occur during digoxin infusion. In high-dose experiments, significant inhibition of cortical and medullary enzyme in the contralateral control kidney was also observed, but natriuresis did not occur. In these experiments the rate at which digoxin reached the control kidney rose progressively but never equaled the rates in the directly infused kidney with either dose. Nevertheless, it is clear that under certain circumstances enzyme inhibition of either cortex or medulla need not be accompanied by natriuresis. We conclude that the major role of renal $\mathrm{Na}^{+}, \mathrm{K}^{+}$-ATPase is in sodium reabsorption in the medulla (ascending limb of Henle's loop) and that it has a relatively small role in proximal sodium reabsorption. The

Dr. Tsaparas is a Hoechst International Fellow in Nephrology.

Received for publication 30 November 1971 and in revised form 17 May 1972. kidney can rely on other sodium reabsorptive mechanisms depending on the rate of enzyme inhibition, so that natriuresis may not occur at all if depression in activity occurs "slowly." The nature of these mechanisms is not clear.

\section{INTRODUCTION}

Sodium-potassium-activated adenosine triphosphatase has been shown to be intimately related to the transport of sodium and potassium across epithelial membranes of numerous tissues (1). The kidney, a major function of which is sodium reabsorption, is no exception, its total enzyme activity being one of the highest of all organs (2). Both cortical and medullary renal tissues are rich in $\mathrm{Na}^{+}, \mathrm{K}^{+}$-ATPase. It is of importance that the enzyme activity in the medulla is at least two to four times higher than that of cortex (3-6). The bulk of cortical tissue consists mainly of proximal convolutions, a site where isosmotic sodium reabsorption takes place. The renal medulla, on the other hand, contains principally the loops of Henle, whose major function is sodium reabsorption and the consequent dilution or concentration of the urine. In a recent report from these laboratories, it was shown that infusion of a cardiac glycoside into one renal artery of dogs leads to a profound decrease in the capacity to concentrate and dilute the urine, manifested by a decrease in free water clearance $\left(\mathrm{C}_{\mathrm{H}_{2} \mathrm{O}}\right)^{1}$ and free water reabsorption $\left(\mathrm{T}^{\mathrm{c}} \mathrm{H}_{2} \mathrm{O}\right)(3,7)$. Accompanying these alterations was a marked reduction in the activity of cortical

\footnotetext{
${ }^{1}$ Abbreviations used in this paper: $\mathrm{C}_{\mathbf{H}_{2} \mathbf{O}}$, free water clearance; $\mathrm{C}_{\mathrm{osm}}$, osmolar clearance; $\mathrm{C}_{\mathrm{PAH}}$, clearance of para-aminohippurate; DOC, sodium deoxycholate; $\mathrm{PAH}$, para-aminohippurate; $\mathrm{PK}-\mathrm{LDH}$, pyruvate kinase-lactate dehydrogenase; $\mathrm{T}^{\mathbf{c}} \mathrm{H}_{2} \mathrm{O}$, fractional solute free water reabsorption; $\mathrm{U}_{\mathrm{Na}} \mathrm{V}$ and $\mathrm{FE}_{\mathrm{Na}}$, absolute and fractional sodium excretion.
} 
and medullary $\mathrm{Na}^{+}, \mathrm{K}^{+}$-ATPase (3). The association of diminished medullary enzyme activity and impaired $\mathrm{C}_{\mathbf{H}_{2} \mathrm{O}}$ and $\mathrm{T}^{\mathrm{c}} \mathrm{H}_{20}$ led us to propose that $\mathrm{Na}^{+}, \mathrm{K}^{+}$-ATPase may serve an important function in the process of urine concentration and dilution (3). Evidence for the specificity of the inhibition was subsequently obtained when it was found that in vitro binding of tritiated cardiac glycoside to the enzyme isolated from kidneys and infused with digoxin was diminished when compared to control kidneys (8). This finding strengthened the suggestion that the $\mathrm{Na}^{+}, \mathrm{K}^{+}$-ATPase is a pharmacological receptor for the drug. Several groups of investigators have now presented similar results.

The role played by the enzyme in proximal tubular reabsorption is less clear. The increments in sodium excretion reported may be entirely attributed to inhibition of sodium reabsorption in the ascending limb of Henle's loop. At a time when as much as $50 \%$ of cortical enzyme activity was inhibited, over $70 \%$ of the filtered sodium was still being reabsorbed, possibly in the proximal tubule $(3,7,8)$.

The present experiments were designed to further examine the relationship between regional sodium reabsorption and $\mathrm{Na}^{+}, \mathrm{K}^{+}$-ATPase activity. In addition we have tried to delineate critically the correlations between renal electrolyte excretion, dosage of cardiac glycoside, and enzyme inhibition.

\section{METHODS}

Mongrel dogs of either sex were studied. The model previously described $(3,7,8)$ was used in all experiments. Animals were deprived of water for 16-24 hr before the experiment. An hour before commencing, they received $5 \mathrm{U}$ of vasopressin tannate in oil subcutaneously. Surgical procedures were usually finished in an hour, at the end of which a solution of $5 \%$ mannitol and one containing appropriate doses of inulin ${ }^{3} \mathrm{H}$ and para-aminohippurate $(\mathrm{PAH})$ were infused at $2 \mathrm{ml} / \mathrm{min}$ and $0.6 \mathrm{ml} / \mathrm{min}$, respectively. $1-1 \frac{1}{2} \mathrm{hr}$ were allowed to elapse for equilibration.

Hydropenic dogs. In $27 \mathrm{dogs}$, saline $1 \mathrm{ml} / \mathrm{min}$ was infused into the left renal artery during control periods, after which it was changed to a solution containing digoxin. Doses of digoxin ranging from 0.4 to $4.0 \mu \mathrm{g} / \mathrm{kg}$ of body wt per min were infused at a rate of $1 \mathrm{ml} / \mathrm{min}$ until urine flow increased at least $50 \%$ above the mean of the control values. In low-dose experiments the dose of digoxin administered ranged between 0.3 and $2.1 \mathrm{mg}$ total dose and from 0.032 to $0.11 \mathrm{mg} / \mathrm{kg}$; the duration of infusion was from 45 to 210 min. Digoxin administered in high-dose experiments ranged between 0.7 and $2.2 \mathrm{mg}$ total dose infused over 20 to 30 $\mathrm{min}$; and from 0.03 to $0.12 \mathrm{mg} / \mathrm{kg}$. The onset of the diuresis varied between 30 and $70 \mathrm{~min}$ in low-dose experiments; in high-dose experiments diuresis, particularly with 3 and 4 $\mu \mathrm{g} / \mathrm{kg}$ per min, invariably occurred between 10 and $20 \mathrm{~min}$ after starting the infusion. In four experiments the digoxin infusion was terminated within $30 \mathrm{~min}$ of commencing in an attempt to examine if enzyme inhibition occurred in the absence of diuresis or of an increase in sodium excretion. In seven animals of the high-dose group, left renal artery blood flow was measured by electromagnetic flow meter.
The kidneys were removed at the end of the experiment, $\mathrm{Na}^{+}, \mathrm{K}^{+}$-ATPase was isolated and assays carried out.

Hypertonic saline-infused dogs. In seven other dogs the same procedures described above were performed, but at the peak of the digoxin effect hypertonic $(2 \%)$ saline was infused to determine the capacity for free water reabsorption $\left(T^{c}{ }_{H_{2}}\right)$. The experiments were ended at different osmolar clearances ( $\mathrm{C}_{\mathrm{osm}}$ ) and the kidneys removed for enzyme assay.

For the measurement of inulin ${ }^{3} \mathrm{H}$ portions of plasma and urine were pipetted into vials containing $10 \mathrm{ml}$ of Bray's solution and radioactivity determined in a Packard Tri-Carb scintillation spectrometer (Packard Instrument Co., Inc., Downers Grove, Ill.). Appropriate corrections for background and quenching were done. PAH in plasma and urine was determined by AutoAnalyzer (Technicon Co., Inc., Tarrytown, N. Y.). The clearance of both inulin ${ }^{3} \mathrm{H}$ and $\mathrm{PAH}$ were calculated in the standard fashion. Conventional formulae were used for the determination of $\mathrm{C}_{\mathrm{osm}}, \mathrm{T}^{\mathrm{e}} \mathrm{H}_{2} \mathrm{O}$, and $\mathrm{C}_{\mathrm{H}_{2} \mathrm{O}}(3,7)$. Methods for the determination of urine and plasma sodium, potassium, and osmolality have been previously described from this laboratory $(3,7,8)$.

Tissue handling and isolation of $\mathrm{Na}^{+}, \mathrm{K}^{+}$-ATPase. The kidneys were placed in a chilled solution containing $0.25 \mathrm{M}$ sucrose and $1 \mathrm{~ms}$ Tris-EDTA at $\mathrm{pH}$ 7.0. The capsule and surrounding tissue were stripped and cut away, the kidneys weighed and then carefully separated into cortex and medulla without any attempt at separating the medulla into inner and outer zones.

All of the following procedures were carried out at $4^{\circ} \mathrm{C}$ and were identical for both cortex and medulla. The isolation method was a modification of the procedure for cardiac tissue (9) and salivary gland (10). The tissue was minced finely with scissors, placed in 9 vol of $0.25 \mathrm{M}$ sucrose, $1 \mathrm{~mm}$ Tris-EDTA, $\mathrm{pH} 7.0$, and homogenized for two $20 \mathrm{sec}$ periods in a Polytron (Brinkmann Instruments Inc., Westbury, N. Y.) at a rheostat setting of 2 (it was found that a Sorvall Omnimixer or Waring blender yielded an inactive preparation). The homogenate was filtered through four and then eight layers of cheesecloth; the filtrate was centrifuged at $10,000 \mathrm{~g}$ for $15 \mathrm{~min}$ in a Sorvall $\mathrm{RC} 2-\mathrm{B}$ refrigerated centrifuge (Ivan Sorvall, Inc., Norwalk, Conn.). The supernatant fluid was discarded and the pellet resuspended in 8 vol of a solution containing $0.25 \mathrm{M}$ sucrose, $1 \mathrm{mM}$ TrisEDTA and $0.1 \%$ sodium deoxycholate (DOC) by means of the Polytron, for six $30 \mathrm{sec}$ periods, with a $15 \mathrm{sec}$ rest in ice after each step. The suspension was kept in ice for $30 \mathrm{~min}$ after the addition of 1 drop of octyl alcohol to decrease foaming and stirred periodically. Another drop of octyl alcohol was usually added after 10-15 min, if the foam was excessive. The resulting mixture was centrifuged at $10,000 \mathrm{~g}$ for $30 \mathrm{~min}$ and the supernatant carefully separated through eight layers of cheesecloth (pellet discarded) and centrifuged at $100,000 \mathrm{~g}$ for $1 \mathrm{hr}$. The resulting high-speed pellet was suspended by means of a glass homogenizer and Teflon pestle in $1.5 \mathrm{vol}$ (relative to the original tissue weight) of $0.25 \mathrm{M}$ sucrose, $1 \mathrm{~mm}$ Tris-EDTA, and $0.05 \%$ $\mathrm{DOC}$ and was centrifuged for $20 \mathrm{~min}$ at $20,000 \mathrm{~g}$. The resulting supernatant was then centrifuged at $100,000 \mathrm{~g}$ for $1 \mathrm{hr}$. This pellet was then suspended in $1 \mathrm{~mm}$ Tris-EDTA and used for $\mathrm{Na}^{+}, \mathrm{K}^{+}$-ATPase assay and ouabain- ${ }^{8} \mathrm{H}$ binding studies. For reasons previously stated (8) routine sodium iodide treatment to further purify the $\mathrm{Na}^{+}, \mathrm{K}^{+}-\mathrm{ATPase}$ was not utilized.

Spectrophotometric assay of $\mathrm{Na}^{+}, \mathrm{K}^{+}$-ATPase. The pyruvate kinase-lactate dehydrogenase (PK-LDH)-linked en- 
TABLE I

Renal Hemodynamic Changes*

\begin{tabular}{|c|c|c|c|c|}
\hline & GFR & CPAH & RBF & MABP \\
\hline & $\mathrm{ml} / \mathrm{min}$ & $m l / m i n$ & $m l / \min$ & $m m \mathrm{Hg}$ \\
\hline \multicolumn{5}{|c|}{ Low-dose experiments $(n=13)$} \\
\hline Control & $23.81 \pm 6.21$ & $80.62 \pm 36.86$ & - & $113 \pm 26$ \\
\hline Experimental & $21.23 \pm 6.54$ & $58.83 \pm 30.10$ & - & $117 \pm 29$ \\
\hline \multicolumn{5}{|c|}{ High-dose experiments $(n=10)$} \\
\hline Control & $23.61 \pm 9.18$ & $65.14 \pm 24.54$ & $182 \pm 65$ & $115 \pm 28$ \\
\hline Experimental & $20.86 \pm 7.76$ & $55.65 \pm 26.37$ & $190 \pm 79$ & $116 \pm 27$ \\
\hline
\end{tabular}

GFR, glomerular filtration rate, RBF, renal blood flow; MABP, mean arterial blood pressure.

* Mean \pm SD; all values refer to digoxin-infused kidney.

¥ Electromagnetic flow meter measurements done in only seven dogs in high-dose group.

zyme assay procedure employed was identical to that already published in detail $(8,11)$. Briefly, the PK-LDH method consists of monitoring NADH oxidation at $340 \mathrm{~m} \mu$ with a recording spectrophotometer. $\mathrm{Na}^{+}, \mathrm{K}^{+}$-ATPase is expressed as that activity which was completely ouabain sensitive (activity in the absence of ouabain minus activity in the presence of $5 \times 10^{-4}$ ouabain). Results were identical using digoxin. All experiments were carried out at $37^{\circ} \mathrm{C}$. Specific activity is expressed as micromoles $\mathrm{Pi}$ per milligram of protein per hour.

Digitalis-s ${ }^{-} H$ binding studies. The procedures were the same as those previously published $(8,9)$. Experiments using digoxin $-{ }^{8} \mathrm{H}$, rather than ouabain $-{ }^{8} \mathrm{H}$, yielded the same results. Since we have previously reported the results of binding studies in experiments utilizing doses of digoxin below $1.0 \mu \mathrm{g} / \mathrm{kg}$ per min (8), only those experiments in which higher doses were used are reported herein.

\section{RESULTS}

Changes in systemic blood pressure, glomerular filtration rate, clearance of PAH, renal blood flow, and mean ar- terial blood pressure before and after digoxin infusion are shown in Table I. A fall in glomerular filtration rate was seen in all experiments. CPAB remained unchanged in some experiments, but on the average fell in both lowand high-dose experiments, more so in the former than in the latter. Renal blood flow, measured by electromagnetic flow meter, did not change appreciably in high-dose experiments. Therefore, filtration fraction tended to rise in low-dose experiments, while it tended to fall in highdose experiments. Blood pressure was not altered significantly throughout the experiments.

The effects of digoxin on absolute $\left(\mathrm{U}_{\mathrm{Na}} \mathrm{V}\right)$ and fractional sodium excretion ( $\left.\mathrm{FEN}_{\mathrm{Nz}}\right), \mathrm{Na}^{+}, \mathrm{K}^{+}$-ATPase activity, and ouabain $-{ }^{8} \mathrm{H}$ binding are shown in Table II. In experiments where digoxin was administered in doses below $1.0 \mu \mathrm{g} / \mathrm{kg}$ per min (low dose) for longer than 30 min, and in all experiments where the dose equaled or exceeded $1.0 \mu \mathrm{g} / \mathrm{kg}$ per min (high dose) and the infusion time was at least 20 min, there was a sharp rise in $U_{\mathrm{Na}} \mathrm{V}$ and $\mathrm{FE}_{\mathrm{Na} .}$ Enzyme activity in cortex and medulla in the contralateral control kidney in low-dose experiments was comparable to that previously reported by us (3). In this group of experiments, the reduction in $\mathrm{Na}^{+}, \mathrm{K}^{+}$-ATPase in the infused kidney was also similar to that observed in a previous study (3). During high-dose infusion, the experimental kidney cortex and medullary activities were reduced by $79 \%$ and $63 \%$, respectively, when compared with the contralateral kidney, and by $87 \%$ and $74 \%$ when compared with the uninfused kidney of low-dose experiments (control). The changes in cortical and medullary activity in the contralateral kidney in the high-dose experiments are comparable to those observed in the experimental kidney of low-dose experiments. The incre-

TABLE II

Effects of Digoxin on Sodium Excretion and $\mathrm{Na}^{+}, \mathrm{K}^{+}-A$ TPase Activity and Binding*

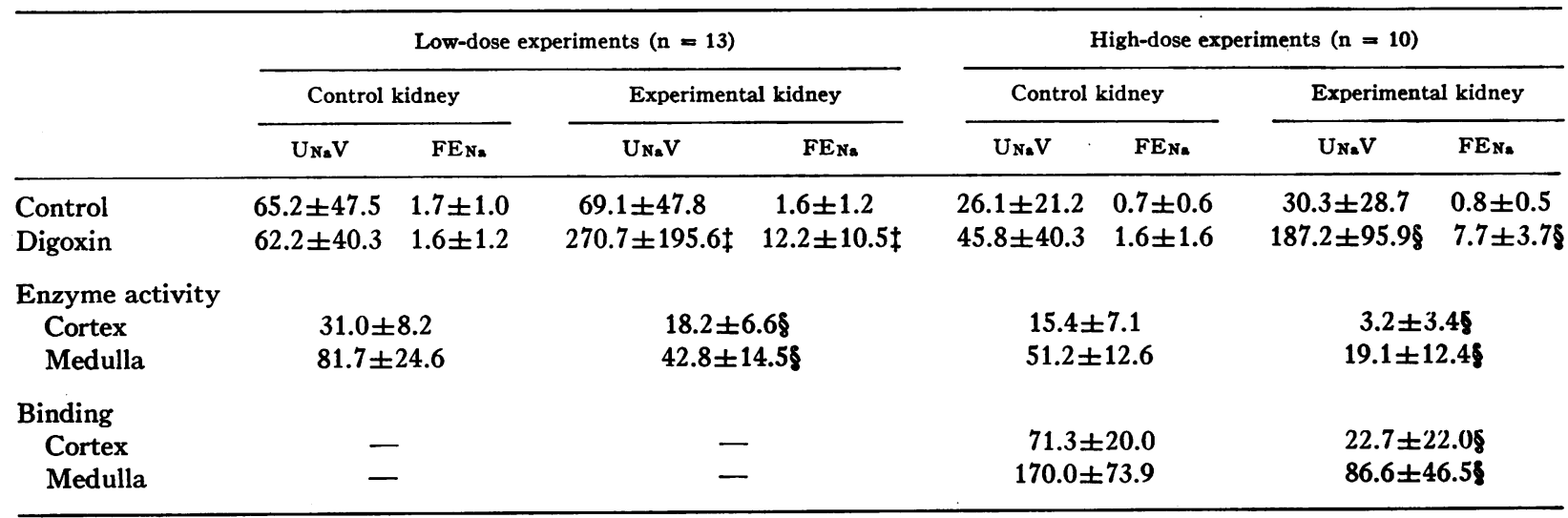

* Mean $\pm \mathrm{SD} ; \mathrm{U}_{\mathrm{Na}} \mathrm{V}=$ sodium excretion $(\mu \mathrm{Eq} / \mathrm{min}) ; \mathrm{FE}_{\mathrm{Na}}=$ fractional sodium excretion $(\%)$; enzyme activity is in $\mu \mathrm{moles}$

$\mathrm{Pi} / \mathrm{mg}$ protein per $\mathrm{hr}$; binding is in pmoles ouabain- ${ }^{2} \mathrm{H} / \mathrm{mg}$ protein.

$\ddagger$ Statistically significant from all other values $(P<0.002)$.

Statistically significant from control $(P<0.001)$. 
TABLE III

Effects of Short Digoxin Infusion on Electrolyte Excretion and Enzyme Activity*

\begin{tabular}{|c|c|c|c|c|c|c|c|c|c|c|c|c|c|c|c|c|c|}
\hline \multirow{2}{*}{$\begin{array}{l}\text { Exp. } \\
\text { No. }\end{array}$} & \multirow{2}{*}{\multicolumn{2}{|c|}{ Dose }} & \multirow{2}{*}{$\begin{array}{l}\text { Length } \\
\text { of } \\
\text { infusion }\end{array}$} & \multicolumn{2}{|c|}{$\Delta \mathrm{UsaV}_{\mathrm{s}}$} & \multicolumn{2}{|c|}{$\Delta \mathrm{C}_{\text {osm }}$} & \multicolumn{2}{|c|}{$\Delta \mathrm{T}^{\mathbf{e}_{\mathrm{H}_{2} \mathrm{O}}}$} & \multicolumn{2}{|c|}{$\Delta \% \mathrm{FE}_{\mathrm{Na}}$} & \multicolumn{4}{|c|}{ ATPase activity } & \multicolumn{2}{|c|}{$\% \Delta$ activity } \\
\hline & & & & C & $\mathrm{E}$ & C & $\mathbf{E}$ & C & $\mathrm{E}$ & $\mathrm{C}$ & $\mathrm{E}$ & $\mathrm{CC}$ & $\mathbf{C M}$ & EC & EM & $(\mathrm{CC}-\mathrm{EC}) / \mathrm{CC}$ & $(\mathrm{CM}-\mathrm{EM}) / \mathrm{CM}$ \\
\hline & $\mu g / k g$ per min & $\mu g / k g$ & $\min$ & \multicolumn{2}{|c|}{$\mu E q / \min$} & \multicolumn{2}{|c|}{$\%$} & \multicolumn{2}{|c|}{$\%$} & \multicolumn{2}{|c|}{$\%$} & \multicolumn{4}{|c|}{$\begin{array}{l}\text { Mmoles } \mathrm{Pi} / \mathrm{mg} \\
\text { protein per } \mathrm{hr}\end{array}$} & & \\
\hline 24 & 0.006 & 0.09 & 15 & 0 & 1 & 0.7 & 0.2 & -0.1 & -0.4 & 0.2 & 0 & 40 & 88 & 32 & 92 & -20 & +4 \\
\hline 25 & 0.007 & 0.21 & 30 & -22 & -33 & -1.0 & 0.5 & -0.5 & 0.1 & -0.7 & -1.3 & 42 & 74 & 32 & 78 & -24 & +5 \\
\hline 26 & 0.008 & 0.24 & 30 & -10 & -40 & -0.5 & -0.2 & -0.3 & 0.2 & -0.6 & -2.2 & 34 & 64 & 20 & 63 & -41 & -2 \\
\hline 27 & 0.010 & 0.30 & 30 & -98 & -56 & -0.2 & 0 & -0.1 & -0.2 & -5.1 & -2.8 & 36 & 74 & 30 & 78 & -17 & +5 \\
\hline
\end{tabular}

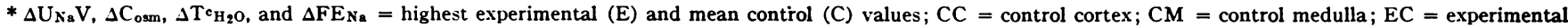
cortex: $\mathrm{EM}=$ experimental medulla.

ments in $\mathrm{U}_{\mathrm{x}_{\mathrm{a}} \mathrm{V}}$ and $\mathrm{FE}_{\mathrm{Na}}$ in the experimental kidneys in high- and low-dose studies were not significantly different from each other (low dose $U_{\mathrm{Na}_{\mathrm{a}} \mathrm{V}}$ vs. high-dose $\mathrm{U}_{\mathrm{Na}} \mathrm{V}$, $P=0.2$; low-dose $\mathrm{FE}_{\mathrm{Na}}$ vs. high-dose $\mathrm{FE}_{\mathrm{Na}}, P>0.1$ ) despite the significant differences in the absolute cortical and medullary enzyme activities between the two groups. More striking was the fact that in the contralateral kidney of the high-dose group there was no significant change in $\mathrm{UNaV}_{\mathrm{a}}$ or $\mathrm{FE}_{\mathrm{Na}}$ despite a degree of enzyme inhibition similar to that of low-dose kidneys. Ouabaininsensitive ATPase remained unchanged in all experiments.

As in previous studies using low doses of digoxin (8), enzyme isolated from kidneys infused with high doses of digoxin exhibited a reduced in vitro binding capacity for ouabain ${ }^{3} \mathrm{H}$ (Table II). Furthermore, the decrease in binding was closely related to enzyme inhibition, a fact that is depicted more clearly in Fig. 1. This corroborates the thesis that the enzyme inhibition was a specific effect of the drug and that the enzyme is presumably a pharmacological receptor $(8,11)$.

To further examine the importance of $\mathrm{Na}^{+}, \mathrm{K}^{+}$-ATPase in the cortex, in four experiments utilizing varying doses of digoxin, the infusion was stopped before urine flow had changed. The results of these studies are summarized in Table III. At the time when digoxin was stopped, $\mathrm{U}_{\mathrm{Na}_{\mathrm{Z}} \mathrm{V}}$ and $F E_{\mathrm{Na}}$ were either unchanged or reduced in all experiments. Enzyme activity, however, was reduced in the cortex by an average $20 \%$ but not in the medulla. Similar changes have been previously observed by us (12). Medullary activity was actually slightly higher than in the control in three of the four experiments. The change, however, was so small that it should not be construed as being the result of enzyme "stimulation" (13).

In the experiments in which $2 \%$ saline was administered during intrarenal infusion of the high dose of digoxin. $\mathrm{T}^{\mathbf{c}} \mathrm{H}_{2} \mathrm{O}$ was markedly impaired (Fig. 2). At the peak of the digoxin effect the capacity of the infused kidney to reabsorb solute-free water was reduced from 17 to $75 \%$ at the particular levels of $\mathrm{C}_{\mathrm{osm}}$ reached, when compared with the contralateral kidney. The relationship between the per cent $T_{\mathrm{H}_{2} \mathrm{O}}^{\mathrm{c}}$ inhibition and the decrease in medullary $\mathrm{Na}^{+}, \mathrm{K}^{+}$-ATPase activity, illustrated in Fig. 3, indicates a direct relationship between reduction in $\mathrm{T}_{\mathrm{H}=\mathrm{O}}^{\mathrm{c}}$ and ATPase inhibition. The regression equation for this relationship is $y=-39.67+1.29 x$, with a linear correlation coefficient of 0.799 , significant at $P<0.05$. Although the cortical $\mathrm{Na}^{+}, \mathrm{K}^{+}-\mathrm{ATP}$ ase was inhibited approximately to the same extent as the medullary enzyme, a correlation between the former and $T^{\mathbf{c}}{ }_{\mathrm{H}_{2} \mathrm{O}}$ would be physiologically meaningless, since cortical structures do not contribute to $\mathrm{T}^{\mathrm{c}} \mathrm{H}_{20}$ (14).

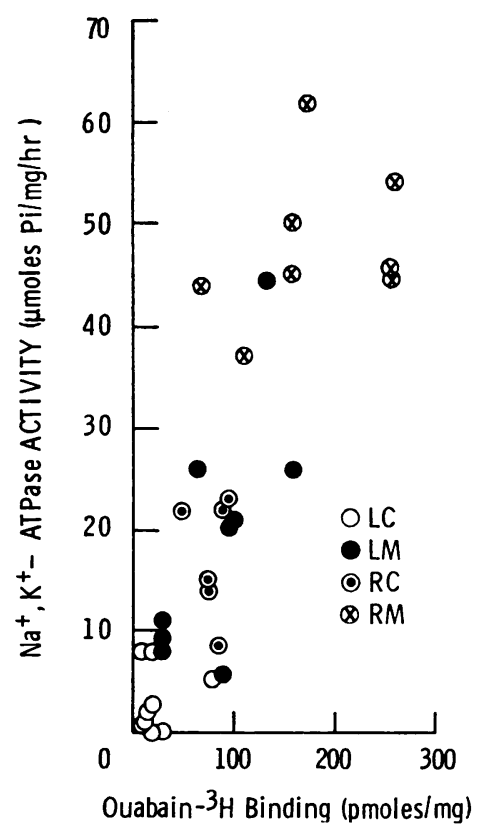

FIgURE 1 Relationship between $\mathrm{Na}^{+}, \mathrm{K}^{+}$-ATPase activity and in vitro binding of ouabain ${ }^{-3} \mathrm{H}$ in all high-dose experiments. $\mathrm{LC}=$ left cortex; $\mathrm{LM}=$ left medulla $; \mathrm{RC}=$ right cortex ; $\mathrm{RM}=$ right medulla. The regression line is $y=33.5495+$ $2.38816(x)$; the correlation coefficient is 0.693113 , significant at a $P<0.001$. 


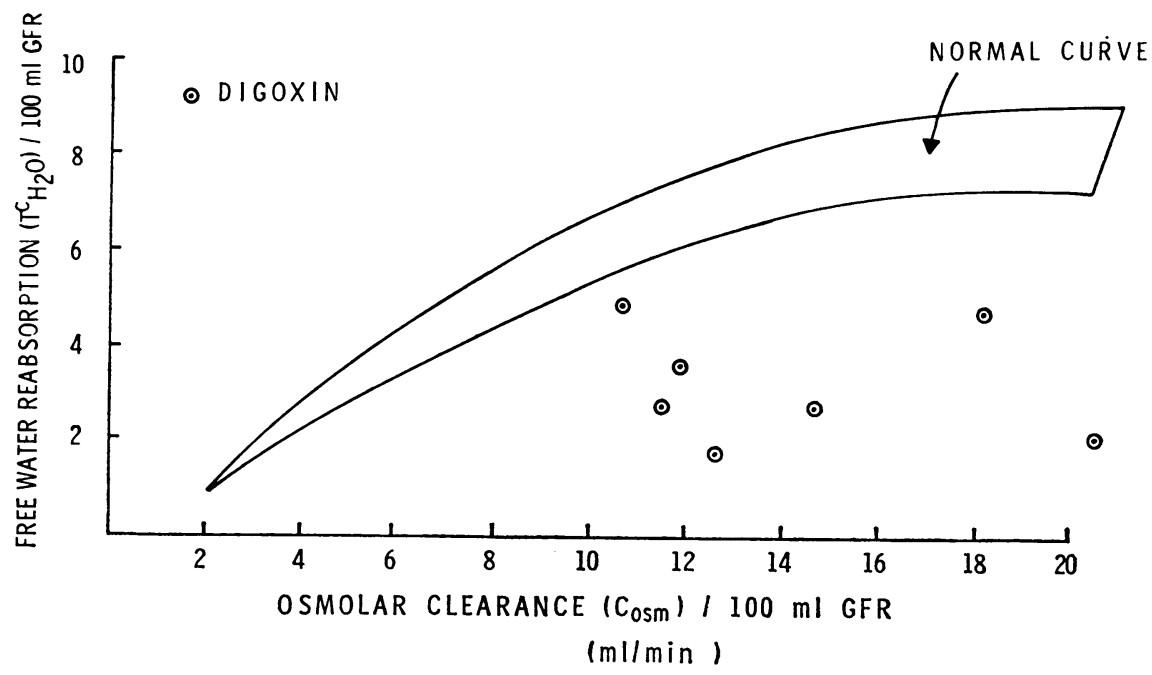

FigURE 2 Relationship between fractional free water reabsorption $\left(\mathrm{T}^{\mathrm{c}} \mathrm{H}_{2} \mathrm{O} / \mathrm{GFR} \times\right.$ $100)$ and fractional osmolar clearance $\left(\mathrm{C}_{\mathrm{osm}} / \mathrm{GFR} \times 100\right)$ during $2 \%$ saline diuresis. Normal curve represents values for control kidney. The points represent maximal $\mathrm{T}^{\mathrm{c}} \mathrm{H}_{2} \mathrm{O}$ obtained in the digoxin infused kidney in seven experiments.

Statistical analyses of the relationships between dose of digoxin, sodium excretion, and per cent change in $\mathrm{Na}^{+}, \mathrm{K}^{+}$-ATPase were performed. There was no relationship between changes in $\mathrm{U}_{\mathrm{Na}} \mathrm{V}$ or $\mathrm{FE}_{\mathrm{Na}}$ and/or total dose or the rate of digoxin administration. The per cent change in $\mathrm{Na}^{+}, \mathrm{K}^{+}$-ATPase activity in both cortex and medulla was a direct function of both the rate of digoxin administration and total dose (the higher these were, the greater the per cent inhibition.) The equation relating the rate of digoxin administration to the change in $\mathrm{Na}^{+}, \mathrm{K}^{+}$-ATPase activity for the left cortex is $y^{\prime}=36.9+$ 13.8x $(P<0.006)$; for the left medulla, $y=39.5+$ $9.99 x(P<0.003)$. The equation relating total digoxin dose to the change in $\mathrm{Na}^{+}, \mathrm{K}^{+}$-ATPase activity for the left cortex is $y=29.5+24.7 x \quad(P<0.04)$; for the left

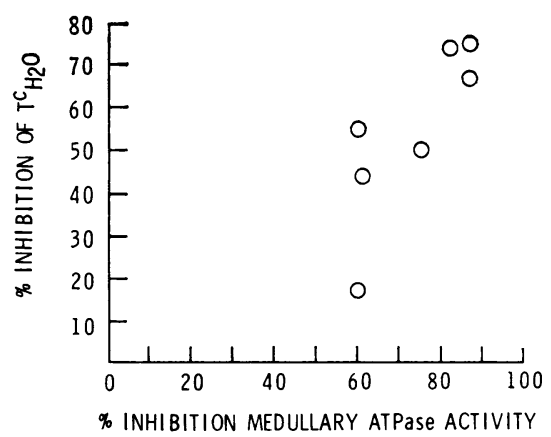

FIGURE 3 Relationship between $\mathrm{Na}^{+}, \mathrm{K}^{+}$-ATPase activity and $\mathrm{T}^{\mathrm{c}} \mathrm{H}_{2} \mathrm{O}$ after digoxin infusion. Per cent inhibition of $\mathrm{T}^{\mathbf{c}}{ }_{\mathrm{H}_{2} \mathrm{O}}$ at each level of $\mathrm{C}_{\text {osm }}$ was calculated from data shown in Fig. 2. The regression line and the correlation coefficient are given in the text; $P<0.050$. medulla, $y=30.6+21.3 x(P<0.005)$. The changes in sodium excretion, absolute or fractional, did not correlate with the per cent change in cortical or medullary $\mathrm{Na}^{+}, \mathrm{K}^{+}-$ ATPase activity in the experimental kidney. There was no relation between the weight of the kidney and the total dose infused as it refers to inhibition of enzyme.

\section{DISCUSSION}

The present experiments confirm our previous results and those of others indicating that $\mathrm{Na}^{+}, \mathrm{K}^{+}$-ATPase is important in the process of sodium reabsorption by the kidney, particularly in the ascending limb of Henle's loop $(3-6,15,16)$. Except when the digoxin infusion was purposely stopped, the glycoside resulted in a rise in sodium excretion in the infused kidney in all experiments. Furthermore, when the capacity to concentrate the urine was examined, a marked reduction in free water reabsorption ( $\left.\mathrm{T}_{\mathrm{H}_{2} \mathrm{O}}^{\mathrm{c}}\right)$ at all levels of osmolar clearance $\left(\mathrm{C}_{\mathrm{osm}}\right)$ was observed in the experimental as compared with the contralateral kidney. These alterations in urine sodium excretion and $T^{c}{ }_{\mathrm{H}: \mathrm{O}}$ were always accompanied by significant inhibition of enzyme activity, the degree of inhibition exceeding $80 \%$ of control activity in some of the high-dose experiments.

From the present results may be derived, in part, the sites in the nephron where digoxin exerts its primary effect and the relative contribution of cortical and medullary ATPase to sodium reabsorption. As seen in Table II, during low-dose infusion a reduction in enzyme activity in the experimental kidney of 42 and $43 \%$, in cortex and medulla, respectively, was associated with a marked rise in $U_{\mathrm{Na}} \mathrm{V}$ representing $12 \%$ of the filtered 
load. Approximately $90 \%$ of the filtered sodium, therefore, continued to be reabsorbed in the presence of this degree of enzyme inhibition. Since during hydropenia at least $20 \%$ of the filtered sodium is reabsorbed in the loop of Henle, inhibition of this segment as indicated by decreased $\mathrm{T}^{\mathrm{c}}{ }_{\mathrm{H}_{2} \mathrm{O}}$ (14) is adequate to explain the natriuresis observed. To examine further the possible role of $\mathrm{Na}^{+}, \mathrm{K}^{+}$-ATPase in sodium reabsorption by the proximal tubule, in four experiments the infusion of low doses of digoxin was deliberately stopped within $30 \mathrm{~min}$ ( Table III). Medullary enzyme activity was not different from control, while that of cortical tissue was reduced in all experiments; $\mathrm{U}_{\mathrm{Na}} \mathrm{V}$ and $\mathrm{T}^{\mathrm{c}} \mathrm{H}_{\mathbf{2}} \mathrm{O}$ remained unchanged, or fell slightly. If the enzyme inhibition would have been accompanied by diminished proximal reabsorption one might expect, with the rise in distal delivery, a rise in $\mathrm{T}^{\mathrm{c}}{ }_{\text {B20 }}$. It might be concluded, therefore, that $\mathrm{Na}^{+}, \mathrm{K}^{+}$ATPase inhibition of this magnitude in the proximal tubule does not lead to significant depression of sodium reabsorption. It is also possible that the degree of enzyme inhibition obtained leads to such small changes in proximal sodium reabsorption that increases in distal delivery may not be discernible from clearance studies. Whichever of these alternatives is correct, it is clear that cortical enzyme activity may be depressed by as much as $41 \%$ (experiment 26, Table III), and without a rise in sodium excretion. That inhibition of proximal reabsorption can occur without sodium diuresis has been demonstrated by micropuncture experiments $(17,18)$.

The extent to which $\mathrm{Na}^{+}, \mathrm{K}^{+}$-ATPase participates in proximal reabsorption can be further examined during the high-dose experiments. In the infused kidney cortical enzyme activity was reduced by $76 \%$ when compared with its contralateral control kidney and by $87 \%$ when compared with contralateral kidneys from low-dose experiments. Moreover, in six experiments the activity was virtually undetectable (less than $3 \mu$ moles $\mathrm{Pi} \mathrm{mg}$ protein $/ \mathrm{hr}$ ), yet in all cases at least $90 \%$ of total filtered sodium continued to be reabsorbed. Since a marked inhibition of medullary ATPase, accompanied by depression of $\mathrm{T}^{\mathrm{c}} \mathrm{H}_{2}$, was seen in these experiments, one only needs to invoke inhibition of sodium reabsorption in the ascending limb of Henle's loop to account for the natriuresis.

Implied in the above discussion is the possibility that part of the sodium reabsorptive machinery in the ascending limb must be inhibited for natriuresis to occur. At first inspection, this hypothesis may appear unjustified. When compared with the infused kidney of the lowdose experiments, enzyme inhibition in the contralateral kidneys of high-dose experiments was of the same magnitude in both cortex and medulla, yet no sodium diuresis occurred. On the other hand, enzyme activity in the cortex and medulla of the control kidney of high-dose ex-

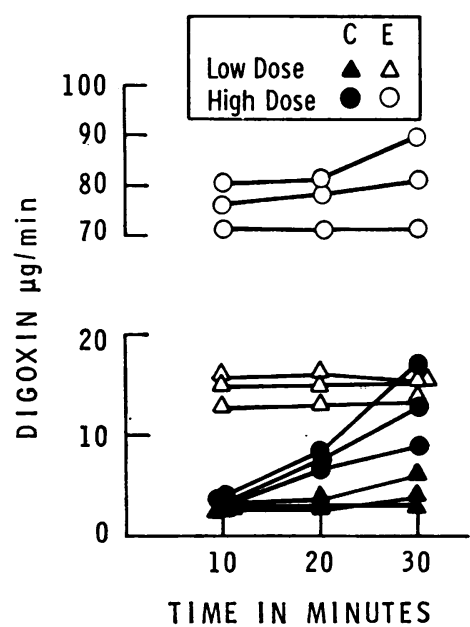

FIgURe 4 Rate at which digoxin reaches the control (C) and experimental (E) kidneys and high-dose experiments. For high-dose experiments the time of infusion was $30 \mathrm{~min}$ and all experimental points are shown. For low-dose experiments only the last three periods (10 min each) of a $60 \mathrm{~min}$ infusion are shown. Determinations of digoxin were made by radioimmunoassay (Schwarz/Mann Laboratories).

periments was still 2.5- to 4-fold of the activity of either cortex or medulla of the infused kidney. A similar observation has been made by Nelson and Nechay (19). A possible explanation for this discrepancy is that in the directly infused kidney the portion of the sodium reabsorptive system dependent on $\mathrm{Na}^{+}, \mathrm{K}^{+}$-ATPase is overwhelmed and cannot, as may the other kidney where inhibition presumably takes place at a slower rate, call into play other mechanisms to reabsorb sodium. ${ }^{2}$ One such mechanism may be a second pump insensitive to cardiac glycosides as in the "two-pump" system recently proposed by Whittembury and his collaborators $(25,26)$. From studies of renal cortical slices they have suggested that the renal tubule has an ion "pump" which is inhibited by ouabain, and another which is inhibited by ethacrynic acid. It may not be unreasonable to suggest that inhibition of one pump allows the other one to compensate for the transport of sodium. It is conceivable that a similar mechanism exists not only in the proximal tubule but in the ascending limb of Henle's as well. Even though digoxin is obviously reaching the control kidney

\footnotetext{
It is now apparent that alterations in peritubular capillary hydrostatic and oncotic pressures (20-23) and in ionic composition of peritubular blood (24) may influence proximal reabsorption. Whether these also influence reabsorption in the loop of Henle is not known. Nevertheless, when measured in high-dose experiments, filtration fraction and sodium reabsorption were depressed, suggesting that changes in peritubular oncotic pressure may have influenced proximal reabsorption. On the other hand, systemic blood pressure and plasma ionic composition remained unchanged throughout the experiments.
} 
through the circulation, the rate at which the glycoside arrives at the receptor is lower than in the experimental kidney and this permits adjustments in sodium reabsorption to supervene. To examine this point, the levels of digoxin in renal arterial blood were determined by radioimmunoassay (Schwarz/Mann Radioimmunoassay Kit for Digoxin, Orangeburg, N. Y.) in three low-dose and three high-dose experiments. The results, summarized in Fig. 4, show that, indeed, the rate at which digoxin reaches the control kidney during high-dose experiments is initially similar to that of the control kidney in low-dose experiments and rises gradually until it is in the range of the rate of delivery to the experimental kidney in low-dose experiments. By contrast, the rate at which digoxin reaches the experimental kidney is steadily high in both low- and high-dose experiments.

Another explanation to the above observations is that a given unit of enzyme activity may be capable of increasing its transport potential when the concentration of glycoside reaching the recepotor and the rate of inhibition are low or gradual. Since enzyme specific activity is higher in the medulla, it is at this site where the capacity to do this might be more likely. This is an attractive suggestion, since it could explain the observed ability of the loop of Henle to reabsorb large amounts of sodium without evidence of saturation during circumstances of increased delivery (27). It is not possible at present to distinguish between these two possibilities.

An inescapable alternative may be that the inhibitory effects of digoxin, as measured, do not reflect the true role of the enzyme in the cellular transport of sodium. The association between the natriuresis and enzyme inhibition may be fortuitous; in fact, despite significant correlations between rate of administration and total dose of digoxin and inhibition of enzyme in cortex and medulla, no statistically significant relationship between sodium excretion and alterations in enzyme activity is detectable in these experiments. A significant correlation between sodium reabsorption and $\mathrm{Na}^{+}, \mathrm{K}^{+}$-ATPase activity, however, has been demonstrated by Nechay and Nelson (4). These investigators utilized whole-kidney tissue homogenates, while we have compared the changes in specific portions of the kidney, which may explain this difference. Insofar as $T^{c}{ }_{\mathrm{H}_{2}}$ is an index of sodium reabsorption in the medulla, it is clear from our experiments that a correlation does exist between this parameter and medullary enzyme inhibition (Fig. 4).

In relation to proximal tubular reabsorption. it may be reasonable to assume that, although $\mathrm{Na}^{+}, \mathrm{K}^{+}$-ATPase mediates the process of isosmotic reabsorption, its contribution is relatively small, and when enzyme activity is depressed, other mechanisms may become operative. That $\mathrm{Na}^{+} \cdot \mathrm{K}^{+}$-ATPase may indeed participate in proximal sodium reabsorption can be adduced from the recent ex- periments by Burg and Orloff (28). The small transtubular potential difference present in isolated proximal tubules can be abolished by addition of $10^{-5} \mathrm{M}$ ouabain to the bathing medium.

As in previous experiments (8), it was important to examine the specificity of changes in enzyme activity. Evidence for the specificity of these changes is indicated by the fact that in vitro binding of ouabain ${ }^{3} \mathrm{H}$ to the enzyme isolated from digoxin-infused kidneys was also reduced. Alterations in binding following inhibition of enzyme-specific activity occurred in both cortex and medulla and were proportional to the reduction in $\mathrm{Na}^{+}, \mathrm{K}^{+}$-ATPase (Fig. 3). This demonstrates that binding of the drug to enzyme is occurring in vivo. It follows by analogy to the observations in other transporting structures, that the natriuresis and the inhibition of $\mathrm{T}_{\mathrm{H}=\mathrm{O}}^{\mathrm{O}}$ may be the result of enzyme inhibition. The present experiments also strengthen the previous suggestion $(3,7,29,30)$ that the major site of action of digitalis is the distal nephron.

\section{ACKNOWLEDGMENTS}

We wish to thank Miss Diane Rouse, Miss Patricia Rouse, and Mr. Ernest Pace for their skillful technical assistance.

Dr. Schwartz is a Career Research Development Awardee, National Heart Institute (K3 HE 11,875-05).

This work was supported by Veterans Administration Section Grant 101.122, Project 26-71; U. S. Public Health Service Grants HE 05435, HE 43042, HE 07906, HE 05925, HE 13837, HE 13870, HE 12209, RR 00254, and NIH-712493; National Science Foundation Grant No. GB 6895; and a grant from the American Heart Association, Texas Affiliate, Houston Chapter.

\section{REFERENCES}

1. Skou, J. C. 1965. Enzymatic basis for active transport of $\mathrm{Na}^{+}$and $\mathrm{K}^{+}$across cell membrane. Physiol. Rev. 45: 596.

2. Bonting, S. L., K. A. Simon, and N. M. Hawkins. 1961. Studies on sodium-potassium-activated adenosine triphosphatase. I. Quantitative distribution in several tissues of the cat. Arch. Biochem. 95: 416.

3. Martinez-Maldonado, M., J. Allen, G. Eknoyan, W. Suki, and A. Schwartz. 1969. Renal concentrating mechanism: possible role for sodium-potassium activated adenosine triphosphatase. Science (Wash. D. C.). 165: 807.

4. Nechay, B., and J. A. Nelson. 1970. Renal ouabainsensitive adenosine triphosphatase activity and $\mathrm{Na}^{+}$ reabsorption. J. Pharmacol. Exp. Ther. 175: 717.

5. Hendler, E. D., J. Torretti, and F. H. Epstein. 1971. The distribution of sodium-potassium-activated adenosine triphosphatase in medulla and cortex of the kidney. J. Clin. Invest. 50: 1329.

6. Jørgensen, P. L., and J. C. Skou. 1969. Preparation of highly active $\left(\mathrm{Na}^{+}+\mathrm{K}^{+}\right)$-ATPase from the outer medulla of rabbit kidney. Biochem. Biophys. Res. Commun. $37: 39$.

7. Martinez-Maldonado, M., G. Eknoyan, J. C. Allen, W. N. Suki, and A. Schwartz. 1970. Urine dilution and 
concentration after digoxin infusion into the renal artery of dogs. Proc. Soc. Exp. Biol. Med. 134: 855.

8. Allen, J. C., M. Martinez-Maldonado, G. Eknoyan, W. N. Suki, and A. Schwartz. 1971. Relation between digitalis binding in vivo and inhibition of sodium, potassium adenosine triphosphatase in canine kidney. Biochem. Pharmacol. 20: 73.

9. Matsui, H., and A. Schwartz. 1966. Purification and properties of a highly active ouabain-sensitive $\mathrm{Na}^{+} \mathrm{K}^{+}$dependent adenosine-triphosphatase from cardiac tissues. Biochim. Biophys. Acta. 128: 380.

10. Schwartz, A., and H. Matsui. 1967. Enzymatic mechanisms for active cation transport. In Secretory Mechanisms of Salivary Glands. L. H. Schneyer and C. A. Schneyer, editors. Academic Press, Inc., New York. 75.

11. Schwartz, A., J. C. Allen, and S. Harigaya. 1969. Possible involvement of cardiac $\mathrm{Na}^{+}, \mathrm{K}^{+}$-adenosine triphosphatase in the mechanism of action of cardiac glycosides. J. Pharmacol. Exp. Ther. 168: 31.

12. Allen, J. C., M. Martinez-Maldonado, G. Eknoyan, W. Suki, and A. Schwartz. 1970. Direct involvement of medullary $\mathrm{Na}^{+}, \mathrm{K}^{+}$-ATPase in digitalis-induced diuresis. Clin. Res. 18: 59 .

13. Palmer, R. F., and B. R. Nechay. 1964. Biphasic renal effects of ouabain in the chicken: correlation with a microsomal $\mathrm{Na}^{+}-\mathrm{K}^{+}$-stimulated ATP-ase. J. Pharmacol. Exp. Ther. 146: 92.

14. Seldin, D. W., G. Eknoyan, W. N. Suki, and F. C. Rector, Jr. 1966. Localization of diuretic action from the pattern of water and electrolyte excretion. Ann. N. Y. Acad. Sci. 139: 328.

15. Schmidt, U., and U. C. Dubach. 1969. Activity of $\left(\mathrm{Na}^{+} \mathrm{K}^{+}\right)$-stimulated adenosinetriphosphatase in the rat nephron. Pfluegers Arch. Eur. J. Physiol. 306: 219.

16. Sejersted, O. M., M. Lie, and F. Kiil. 1971. Effect of ouabain on metabolic rate in renal cortex and medulla. Am. J. Physiol. 220: 1488.

17. Howards, S. S., B. B. Davis, F. G. Knox, F. S. Wright, and R. W. Berliner. 1968. Depression of fractional sodium reabsorption by the proximal tubule of the dog without sodium diuresis. J. Clin. Invest. 47: 1561 .

18. Knox, F. G., S. S. Howards, F. S. Wright, B. B. Davis, and R. W. Berliner. 1968. Effect of dilution and expansion of blood volume on proximal sodium reabsorption. Am. J. Physiol. 215: 1041.
19. Nelson, J. A., and B. Nechay. 1970. Effects of cardiac glycosides on renal adenosine triphosphatase activity and $\mathrm{Na}^{+}$reabsorption in dogs. J. Pharmacol. Exp. Ther. $175: 727$.

20. Bresler, E. H. 1961. Reflections on the nature of renal tubular reabsorption. Am. Heart J. 62: 1.

21. Earley, L. E., and R. M. Friedler. 1966. The effects of combined renal vasodilatation and pressor agents on renal hemodynamics and the tubular reabsorption of sodium. J. Clin. Invest. 45: 542.

22. Lewy, J. E., and E. E. Windhager. 1968. Peritubular control of proximal tubular fluid reabsorption in the rat kidney. Am. J. Physiol. $214: 943$.

23. Brenner, B. M., K. H. Falchuk, R. I. Keimowitz, and R. W. Berliner. 1969. The relationship between peritubular capillary protein concentration and fluid reabsorption by the renal proximal tubule. J. Clin. Invest. 48: 1519.

24. Ullrich, K. J. 1970. Recent advances in nephrology, physiological aspects. Proc. 4th Int. Congr. Nephrol. $1: 8$.

25. Whittembury, G., and F. Proverbio. 1970. Two modes of $\mathrm{Na}$ extrusion in cells from guinea pig kidney cortex slices. Pfluegers Arch. Eur. J. Physiol. 316: 1.

26. Proverbio, F., J. W. L. Robinson, and G. Whittembury. 1970. Sensitivities of $\left(\mathrm{Na}^{+}-\mathrm{K}^{+}\right)-\mathrm{ATPase}$ and $\mathrm{Na}^{+}$ extrusion mechanisms to ouabain and ethacrynic acid in the cortex of the guinea pig kidney. Biochim. Biophys. Acta. 211: 327.

27. Eknoyan, G., W. N. Suki, F. C. Rector, Jr., and D. W. Seldin. 1967. Functional characteristics of the diluting segment of the dog nephron and the effect of extracellular volume expansion on its reabsorptive capacity. J. Clin. Invest. 46 : 1178.

28. Burg, M. B., and J. Orloff. 1970. Electrical potential difference across proximal convoluted tubules. $\mathrm{Am}$. J. Physiol. 219: 1714.

29. Hendler, E. K., J. Torretti, E. Weinstein, and F. H. Epstein. 1969. Functional significance of the distribution of Na-K-ATPase within the kidney. J. Clin. Invest. 48: $37 \mathrm{a}$.

30. Wilde, W. S., and P. J. Howard. 1960. Renal tubular action of ouabain on $\mathrm{Na}$ and $\mathrm{K}$ transport during stopflow and slow-flow technique. J. Pharmacol. Exp. Ther. $130: 232$. 